\title{
COVID-19, A new challenge in the dental practice
}

\author{
Francisco-Javier Silvestre ${ }^{1,2}$, Mayte Martinez-Herrera ${ }^{1}$, Cecilia-Fabiana Márquez-Arrico ${ }^{2}$, Javier Silvestre-Rangil ${ }^{1}$
}

\footnotetext{
${ }^{1}$ Department of Stomatology, University of Valencia, Spain

${ }^{2}$ Stomatology Service, Hospital Universitario Dr. Peset-FISABIO
}

Correspondence:

Calle Juan de Garay 21, Stomatology

Hospital Universitario Dr. Peset

Valencia (46017), Spain

Cecilia.fabiana.m@gmail.com

\begin{abstract}
Silvestre FJ, Martinez-Herrera M, Márquez-Arrico CF, Silvestre-Rangil J. COVID-19, A new challenge in the dental practice. J Clin Exp Dent. 2021;13(7):e709-16.
\end{abstract}

Received: 23/05/2020

Accepted: $23 / 01 / 2021$

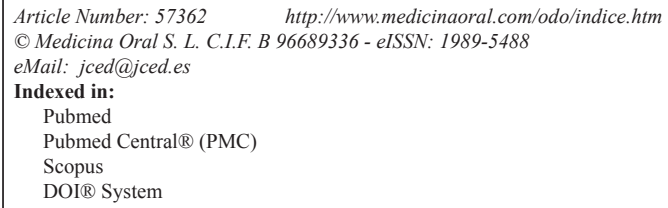

DOI $\Re$ System

\begin{abstract}
Background: This review was conducted in order to learn the latest information about how to prevent cross-infection of COVID-19 in dentistry. The aim of this study is offer a clinical protocol to reduce the risk of infection of COVID-19 in dental settings.

Material and Methods: We carried out a review based on the PRISMA guide (Preferred Reporting Items for Systematic Reviews and Meta-Analyses). We used the following three databases: PubMed, Embase and Scopus. The search strategy was performed in the three databases applying the search terms "COVID-19 AND dental", "COVID-19 AND dentistry", selecting human studies published from November 2019 to May 2020. English publications regarding COVID-19 as the central topic of the research were eligible for inclusion, regardless of study design. There are very few published studies on the association between COVID-19 and dentistry, for that reason we also included the English abstract of two studies written in Chinese. The following exclusion criteria were established: animal studies and in vitro studies.

Results: The search identified a total of 212 articles, of which 54 were preselected, and 23 were finally included in the review on the basis of the inclusion and exclusion criteria. We collected all the information about routes of general and oral infection, dental patient evaluation and cross-infection control in Dental Clinic in the selected studies. Conclusions: Cross infection in the dental clinic involve a very important risk due to the return to dental settings after periods of social isolation of the population after the epidemic outbreak of SARS-CoV-2. Therefore, we must take adequate and sufficient security measures to protect the patients and the dental clinic staff.
\end{abstract}

Key words: COVID-19, COVID-19 cross infection risk, COVID-19 prevention in Dentistry, COVID-19 in Dental Clinic.

\section{Introduction}

Coronavirus disease (COVID-19) is an infectious disease caused by a newly discovered coronavirus. It was discovered in Wuhan, a city of China, at the end of December 2019 and up to the present time, this disease has rapidly spread in the form of a pandemic to most countries around the world (1). The World Health Organization (WHO) announced an international health emergency to this outbreak of severe pneumonia (January $30,2020)(2)$. This novel coronavirus, officially named 
as severe acute respiratory syndrome coronavirus 2 (SARS-CoV-2), has been transmitted as a zoonosis from the reservoir in the Chinese bats (Rhinolophus sinicus) through some mammal being pangolins as the most likely intermediate host to the human (3). It is an RNA virus with a high transmission capacity between persons with a high infectivity index $(\mathrm{R} 0 \approx 2.2)(4)$. Due to the globalization and the ease of interconnection between countries has eased this virus, it has to spread widely around the world in a few weeks due to lack of prior immunity.

The sustained human-to-human spreads include direct transmission by droplets of saliva $(5-10 \mu \mathrm{m})$ (cough, sneeze and droplet inhalation) and contact transmission by droplets deposition on surfaces (contact with nasal, oral and eye mucous) from the presymptomatic period to possibly after the disappearance of symptoms. Furthermore, it is suspected that there may be patients with hardly any symptoms who transmit it to a great extent (5). The virus can persist in various media from a few hours to 2-3 days (in stainless steel and plastic) (6). In addition, there may be a fecal-oral transmission and there is little data regarding a possible vertical transmission (from mothers to their newborns) (7).

To infect a cell, viruses use spike protein (SP) to bind the cell membrane, a process activated by specific cellular enzymes such as trypsin, furin, and cathepsin L. In the literature, it has been originally described that when the coronavirus enters the body, it binds to the human angiotensin-converting enzyme 2 (ACE2) receptor from the cells through the S1 subunit of SP in the membrane envelope from coronavirus $(8,9)$. ACE2 is enzyme that is critical to regulating processes such as blood pressure, wound healing and inflammation, in a biochemical pathway called the renin-angiotensin-aldosterone system (RAAS). The ACE enzyme converts angiotensin I into angiotensin II (ANG II). The main role of ACE2 is to break down angiotensin II into other molecules that counteract the effects of ANG II.

ACE2 helps modulate the many activities of the ANG II, that increases blood pressure and inflammation, increasing damage to blood vessel linings and various types of tissue injury $(8,9)$. In certain tissues such as the lung, a large release of inflammatory mediators (cytokine storm) can occur as an excessive and inadequate inflammatory response (10). It can cause serious tissue damage by the action of certain enzymes (proteases). This situation can lead to severe respiratory distress in the adult with very severe respiratory failure (9-11). The high affinity between ACE2 and coronavirus S1 protein suggested that the population with higher expression of ACE2 might be more susceptible to SARS-CoV-2. Current observations suggest that people of all ages are generally susceptible to this new infectious disease, but in children the infection seems to be milder (7) and in general, older age and the existence of underlying comorbidities (e.g., diabetes, hypertension, and cardiovascular disease) were associated with poorer prognosis (1). However, the pathophysiological mechanism of SARS-CoV-2 is continually being investigated and recently in early April it has been simulated that the virus "attacks" our haemoglobin A. Viral non-structural proteins (named “orf”) dissociate heme on the 1-beta chain of hemoglobin into iron and porphyrin. The attack will lead to less hemoglobin to transport oxygen to human tissues $(11,12)$. Therefore, it is thought that the virus may first infected cells with ACE2 receptors, including immune cells, which produced antibodies. Antibodies and red blood cells will generate immune hemolysis and then the virus will attack hemoglobin, as well as it will capture porphyrin and will inhibit heme metabolism, causing systemic damage to the human body.

The disease has 3 phases. A first infection with a high viral load (during the first 7-10 days). The incubation period of COVID-19 is usually 5 days on average (2 to 14 days), which is now the commonly adopted duration for quarantine of exposed persons (13). After incubation, the majority of patients experience a viral respiratory illness with fever and dry cough, although other symptoms such as sore throat, headaches, fatigue, and other atypical symptoms, such as muscle pain, loss of smell and taste, diarrhoea and vomiting may appear $(1,7)$. In a second phase it can give an inflammatory pulmonary chart (around the 2nd week) and it can continue for a third critical phase with a hyperinflammation and respiratory, renal failure, arrhythmias, thrombosis because the elevation of D-dimer and fibrinogen degradation products facilitates the appearance of thromboembolism, and may end in a sepsis and fatal outcome (14).

Chest tomography (CT) appears to be the most sensitive clinical diagnostic test showing bilateral pneumonia, with ground glass-like infiltrates (14). The evolution is mild in $81 \%$, severe in $14 \%$ and critical in $5 \%$ with significant mortality. Detection should be done by PCR and antibodies against viral antigen can also be detected (15). There are rapid tests that qualitatively detect the presence of $\operatorname{IgG}$ and IgM antibodies against SARSCoV-2, however the most reliable diagnostic test is the PCR method. Treatment is in line with providing early diagnosis with isolation and supportive care for patients with COVID-19. Many clinical trials are currently underway. However, some protocols have been followed so far those seem to work better clinically. Non-clinical indication drugs are used to couple them to COVID-19. Antivirals are used early in the first week as lopinavir and ritonavir. Remdesivir which is much more active has also been used. Interferon, which may have some degree of synergy effect with lopinavir and ritonavir, is associated in the treatment of severe pneumonia, but some patients have shown no improvement with interfe- 
ron treatment (16). Hydroxychloroquine has been used and would have a double effect, antiviral and anti-inflammatory on patients infected with COVID-19, but its effectiveness for COVID-19 is controversial (17). On the other hand, there are anti-inflammatory drugs that have to be administered approximately one week before the patient presents the hyperinflammation chart with severe pneumonia. Corticosteroids as well as IL-6 inhibitors such as tocilizumab have been managed $(16,17)$. Due to the working characteristics in dental clinics, the risk of cross infection may be high among dentists and patients. For dental settings in countries that are affected with COVID-19, strict and effective infection control and action protocols are urgently needed. This article, based on relevant guidelines and recent research, introduces the essential knowledge about COVID-19 and risk of infection in dental settings and provides recommended management protocols for dental practitioners in affected areas. This review was conducted in order to answer the question: How to prevent cross-infection of COVID-19 in dentistry?

\section{Material and Methods}

We carried out a review based on the PRISMA guide (Preferred Reporting Items for Systematic Reviews and Meta-Analyses) (18). We used the following three databases: PubMed, Embase and Scopus. All searches and title and abstract screenings, as well as study selection, were performed independently by two investigators. Discrepancies were resolved by consensus. The search strategy was performed in the three databases applying the search terms "COVID-19 AND dental", "COVID-19 AND dentistry", selecting human studies published the last 6 months (from November 2019 to May 2020). Publications regarding Covid-19 as the central topic of the research were eligible for inclusion, regardless of study design. Therefore, case reports, case series, correspondences and editorials were processed in order to identify COVID-19 prevention and control of cross-infection data. English studies were included. There are very few published studies on the association between COVID-19 and dentistry, for that reason we also included the English abstract of three studies written in Chinese $(12,19,20)$. The following exclusion criteria were established: animal studies and in vitro studies. Once the articles had been identified, we carried out a screening by reading abstracts. The articles whose content was not adapted to COVID-19 and its relationship with cross-infection in dentistry were eliminated. Duplicated articles were also eliminated. The flowchart corresponding to the search process is shown in figure 1 . We collected all the information about routes of general and oral infection, dental patient evaluation and cross-infection control in Dental Clinic in the selected studies.

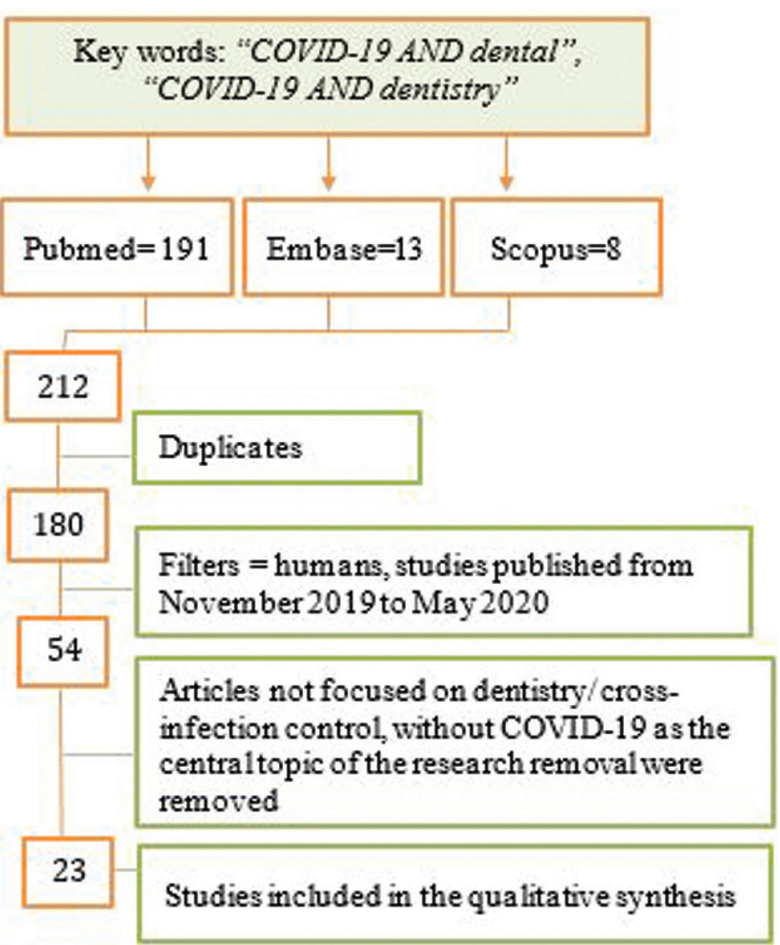

Fig. 1: Flow chart of the selection of articles for the review.

\section{Results}

The search identified a total of 212 articles, of which 54 were preselected, and 23 were finally included in the review on the basis of the inclusion and exclusion criteria. These 23 articles were described in table 1 .

-Routes of general and oral infection

The SARS-CoV-2 virus can be transmitted over short distances $(<2$ meters), by respiratory and saliva droplets (Plügge) and emerging evidence suggested that it may also be indirectly transmitted through contact with contaminated surfaces $(8,21)$. In addition, although the incubation period for individuals infected has been reported to be between 5 and 14 days, it was suspected that those without an evident clinical chart could transmit the infection (5). In the dental clinic, airborne propagation has been demonstrated since many dental procedures produce aerosols when rotating instruments with water spray are used (22). The use of anti-retraction handpieces is advised and encouraged during the COVID-19 pandemic, as these anti-retraction handpieces results in a significant reduction in the backflow of bacteria and virus from oral cavity into the tubes of the handpiece in comparison with a handpiece without anti-retraction function (23).

In addition, aerosols are mixed with saliva or blood drops of the patients and bioaerosols are created. These bioaerosols are microdroplets contaminated with bacteria and viruses that can be directly projected towards 
Table 1: General characteristics of the studies included in the review.

\begin{tabular}{|c|c|c|}
\hline $\begin{array}{l}\text { Author } \\
\text { Journal }\end{array}$ & Study Design & Conclusions \\
\hline $\begin{array}{l}\text { Alharbi et al., } 2020 \text { (29) } \\
\text { Saudi Dental J }\end{array}$ & $\begin{array}{l}\text { Narrative Literature } \\
\text { Review }\end{array}$ & $\begin{array}{l}\text { Is necessary develop guidelines for dental patients' management during and after } \\
\text { the COVID-19. The actual recommendation is treat patients depending on whether } \\
\text { they are Covid-19 infected and the type of treatment they require (urgent or non- } \\
\text { urgent). Therefore, case and treatment categorisation should always be considered. }\end{array}$ \\
\hline $\begin{array}{l}\text { Ather et al., } 2020 \text { (37) } \\
J \text { Endod }\end{array}$ & $\begin{array}{c}\text { Narrative Literature } \\
\text { Review }\end{array}$ & $\begin{array}{l}\text { Initial screening via telephone to identify patients with suspected or possible COV- } \\
\text { ID-19 infection can be performed remotely at the time of scheduling appointments. } \\
\text { Dentists should follow standard, contact, and airborne precautions including the } \\
\text { appropriate use of PPE and hand hygiene practices. Sequence for putting on PPE: } \\
\text { gown, mask, goggles or face shield and gloves. }\end{array}$ \\
\hline $\begin{array}{l}\text { Azzi et al., } 2020 \text { (28) } \\
\text { J Infect }\end{array}$ & $\begin{array}{l}\text { Prospective cohort } \\
\text { study } n=25 \text {, mean age } \\
\quad 61,5 \text { years old }\end{array}$ & $\begin{array}{l}\text { Saliva is a reliable tool to detect SARS-CoV-2. The role of saliva in COVID-19 } \\
\text { diagnosis could not be limited to a qualitative detection of the virus, but it may also } \\
\text { provide information about the clinical evolution of the disease. It has been suggest- } \\
\text { ed that the oral cavity may play an active role in the pathogenesis of COVID-19. }\end{array}$ \\
\hline $\begin{array}{l}\text { Coulthard et al., } 2020 \text { (30) } \\
\text { Br Dent J }\end{array}$ & Letter to the Editor & $\begin{array}{l}\text { Dental drills cause the formation of aerosol and splatter commonly contaminated } \\
\text { with bacteria, viruses, fungi and blood. The following measures are recommended: } \\
\text { hand hygiene, PPE, pre-treatment peroxide of hydrogen mouthwash, rubber dum } \\
\text { isolation, environmental disinfection and FPP2 or FPP3 respirator. }\end{array}$ \\
\hline $\begin{array}{l}\text { Dave et al., } 2020 \text { (38) } \\
\text { Lancet }\end{array}$ & Correspondence & $\begin{array}{l}\text { Dental and oral surgery procedures using drills or ultrasonic devices cause aerosol } \\
\text { release, and routine dentistry has therefore been suspended in several countries. } \\
\text { Testing for COVID-19 in dental professionals should be undertaken with the same } \\
\text { high priority as that of medical health-care workers in hospitals. }\end{array}$ \\
\hline $\begin{array}{l}\text { Fiorillo et al., } 2020(34) \\
\text { Int J Environ Res Public } \\
\text { Health }\end{array}$ & $\begin{array}{c}\text { Narrative Literature } \\
\text { Review }\end{array}$ & $\begin{array}{l}\text { Surface disinfection could be performed with } 0.1 \% \text { sodium hypochlorite or } 62 \%- \\
71 \% \text { ethanol for } 1 \text { minute. Disinfecting surfaces is one of the aspects to which to } \\
\text { give greater attention, along with the washing of hands and the use of suitable PPE. } \\
\text { In regards to PPE, surgical masks must be used by those who could transmit the } \\
\text { virus, but those who work in contact with the patient's aerosol must use FFP2 and } \\
\text { FFP3 masks. }\end{array}$ \\
\hline $\begin{array}{l}\text { Ge et al., } 2020 \text { (22) } \\
J \text { Zheijiang Univ Sci B }\end{array}$ & $\begin{array}{c}\text { Narrative Literature } \\
\text { Review }\end{array}$ & $\begin{array}{l}\text { Special precautions in routine practice: spatial separation of at least } 1 \mathrm{~m} \text { should be } \\
\text { maintained between patients at the waiting area, handwashing, personal protec- } \\
\text { tive equipment, preprocedural mouth rinse, rubber dam isolation, removal/filter of } \\
\text { contaminated air, environmental surface disinfection and others. }\end{array}$ \\
\hline $\begin{array}{l}\text { Hua et al., } 2020 \text { (20) } \\
\text { Hua Xi Kou Qiang Yi Xue } \\
\text { Za Zhi }\end{array}$ & $\begin{array}{c}\text { Narrative Literature } \\
\text { Review }\end{array}$ & $\begin{array}{l}\text { Standard Prevention: Wear disposable work caps, disposable surgical masks, and } \\
\text { work clothes, wear goggles or face masks, and disposable latex gloves or nitrile } \\
\text { gloves if necessary. Advanced Protection: Wear standard prevention and face } \\
\text { shields, work clothes plus disposable isolation suits or surgical clothing. Enhanced } \\
\text { protection: wear advanced protection and disposable work hat, disposable medical } \\
\text { FFP2 or FFP3 mask and leak-proof shoe covers. }\end{array}$ \\
\hline $\begin{array}{l}\text { Khurshid et al., } 2020(25) \\
\text { Int J Environ Res Public } \\
\text { Health }\end{array}$ & $\begin{array}{c}\text { Narrative Literature } \\
\text { Review }\end{array}$ & $\begin{array}{l}\text { Saliva collection is quite comfortable for patients as well as being easy, cheap, and } \\
\text { non-invasive with minimal equipment required. The diagnostic capability of human } \\
\text { saliva for identifying COVID-2019 could be a good screening test. It should also } \\
\text { minimize the nosocomial transmission of } 2019-\mathrm{nCoV} \text { to healthcare workers. }\end{array}$ \\
\hline $\begin{array}{l}\text { Li et al., } 2020 \text { (12) } \\
\text { Zhonghua Kou Qiang Yi } \\
\text { Xue Za Zhi }\end{array}$ & $\begin{array}{c}\text { Narrative Literature } \\
\text { Review }\end{array}$ & $\begin{array}{l}\text { Efficient infection control can prevent the virus from further spreading. Special } \\
\text { precautions in routine practice: mouth rinse before oral examination with povidone } \\
\text { iodine } 1 \% \text { or cetylpyridinium chloride }(0.05-0.10 \%) \text {, avoid aerosols, control of the } \\
\text { dental environment, cleaning and ventilation frequently. It's urgent to implement an } \\
\text { efficient infection control protocol. }\end{array}$ \\
\hline $\begin{array}{l}\text { Lo Guidice. } 2020 \text { (35) } \\
\text { Int. J Environ Res Public } \\
\text { Health }\end{array}$ & Feature Paper & $\begin{array}{l}\text { It is necessary the use of PPE such as gloves, masks, visors, goggles, dental uni- } \\
\text { form, and surgical gown and shoes. A set of decontamination, disinfection, and ster- } \\
\text { ilization procedures aimed at inactivating, destroying, or removing pathogens from } \\
\text { any surface or instruments. The COVID-19 can be inactivated at a temperature of } \\
56{ }^{\circ} \mathrm{C} \text { for } 30 \mathrm{~min} \text {, as well as by } 75 \% \text { ethanol. It is not sensitive to chlorhexidine. }\end{array}$ \\
\hline $\begin{array}{l}\text { Meng et al., } 2020 \text { (1) } \\
\text { J Dent Res }\end{array}$ & $\begin{array}{c}\text { Narrative Literature } \\
\text { Review }\end{array}$ & $\begin{array}{l}\text { For dental practices and hospitals in countries/regions that are affected with CO- } \\
\text { VID-19, strict and effective infection control protocols are urgently needed. The } \\
\text { 4-handed technique is beneficial for controlling infection, the use of saliva ejectors } \\
\text { with low or high volume can reduce the production of droplets and aerosols, the use } \\
\text { of mask, gloves, rubber dum isolation, and other recommendations. }\end{array}$ \\
\hline
\end{tabular}


Table 1 cont.: General characteristics of the studies included in the review.

\begin{tabular}{|c|c|c|}
\hline $\begin{array}{l}\text { Mupparapu et al., } 2020 \\
\text { (36) Quintessence Int }\end{array}$ & Editorial & $\begin{array}{l}\text { Hand hygiene with soap and water or by using an alcohol-based hand sanitizer } \\
\text { should be followed as always. All dental health care personnel should use PPE. Each } \\
\text { patient should be asked for symptoms such us, high temperatures, runny nose, etc. }\end{array}$ \\
\hline $\begin{array}{l}\text { Odeh et al., } 2020 \text { (33) } \\
\text { Int. J. Environ. Res. Public } \\
\text { Health }\end{array}$ & Communication & $\begin{array}{l}\text { Pre-screening patients for symptoms of COVID-19, by phone and/or upon arrival } \\
\text { for treatment should be carried out. Available aerosol reduction, such as use of a } \\
\text { rubber dam, availability of high speed evacuation, alternative treatment measures } \\
\text { that might be employed. PPE must be used and to provide dental treatment. }\end{array}$ \\
\hline $\begin{array}{l}\text { Peng et al., } 2020 \text { (21) } \\
\text { Int J Oral Sci }\end{array}$ & $\begin{array}{c}\text { Narrative Literature } \\
\text { Review }\end{array}$ & $\begin{array}{l}\text { Drops and aerosol are produced during dental treatment. The COVID-19 has the } \\
\text { potential to spread through droplets and aerosols from infected individuals in den- } \\
\text { tal clinics. Special precautions in routine practice: evaluation of the patient, hand } \\
\text { hygiene, previous mouth rinse, PPE, and use of rubber dum. }\end{array}$ \\
\hline $\begin{array}{l}\text { Sabino-Silva et al., } 2020 \\
\text { (26) Clin Oral Investig }\end{array}$ & Letter to the Editor & $\begin{array}{l}\text { Saliva can have a pivotal role in the human-to-human transmission, and non-inva- } \\
\text { sive salivary diagnostics may provide a convenient and cost-effective point-of-care } \\
\text { platform for the fast and early detection of COVID-19 infection. }\end{array}$ \\
\hline $\begin{array}{l}\text { Spagnoulo et al., } 2020(39) \\
\text { Int J Environ Res Pub- } \\
\text { lic Health }\end{array}$ & Overview & $\begin{array}{l}\text { When the dentists treat patients, they should intercept the potentially infected per- } \\
\text { son before they reach the operating areas. The management practice of the operat- } \\
\text { ing area should be quite similar to what happens with other patients affected by } \\
\text { infectious and highly contagious diseases. Handpieces must be equipped with anti- } \\
\text { reflux devices to avoid contaminations, improving the risk of cross-infections. }\end{array}$ \\
\hline $\begin{array}{l}\text { The French Society of Sto- } \\
\text { matology, Maxillo-Facial } \\
\text { Surgery and Oral Surgery } \\
2020 \text { (32) } \\
\text { J Stomatol Oral Maxil- } \\
\text { lofac Surg }\end{array}$ & Professional guidelines & $\begin{array}{l}\text { Recommendations PPE, FFP2 mask, glasses or large face shields, and gloves, } \\
\text { hand cleaning should include all fingers, digital spaces, palms, backs of hands and } \\
\text { clipped nails. Between two patients and at the end of the consultation, systematical- } \\
\text { ly bio-clean the equipment and objects entering into contact with the patient (chin, } \\
\text { hands, etc.), using a usual disinfectant detergent containing at least one quaternary } \\
\text { ammonium (support and handles of X-ray equipment, chair arms, door handles, } \\
\text { etc.). }\end{array}$ \\
\hline $\begin{array}{l}\text { Wang et al., } 2020 \text { (19) } \\
\text { Sichuan Da Xue Xue Bao } \\
\text { Yi Xue Ban }\end{array}$ & $\begin{array}{c}\text { Narrative Literature } \\
\text { Review }\end{array}$ & $\begin{array}{c}\text { It is important to maintain oral health in children at home to maintain good health. } \\
\text { Therefore, its necessary develop good oral habits (brushing teeth properly at home) } \\
\text { and healthy dietary habits. When dental emergencies occur they should visit the } \\
\text { dental clinic with adequate protection. }\end{array}$ \\
\hline $\begin{array}{l}\text { Xu et al., } 2020 \text { (24) } \\
\text { Int J Oral Sci }\end{array}$ & Experimental design & $\begin{array}{l}\text { ACE2 is the main host cell receptor of COVID-19. The expression of the ACE2 } \\
\text { receptor in the oral mucosa was explored. This receptor is expressed in the epithe- } \\
\text { lial cells of the mucosa, especially in the tongue cells. The oral mucosa could be an } \\
\text { infection focus to COVID-19. }\end{array}$ \\
\hline $\begin{array}{l}\text { Yang et al., } 2020 \text { (31) Chin } \\
\text { J Dent Res }\end{array}$ & $\begin{array}{c}\text { Narrative Literature } \\
\text { Review }\end{array}$ & $\begin{array}{l}\text { The healthcare personnel of the Department of Oral and Maxillofacial Surgery } \\
\text { are especially vulnerable to the infection due to their extensive and close exposure } \\
\text { to patients' oral and nasal cavities and secretions. Special precautions in routine } \\
\text { practice: evaluation of the patient, hand hygiene, previous mouth rinse, PPE, use of } \\
\text { rubber dum and avoiding aerosols and disinfection of the environment. }\end{array}$ \\
\hline $\begin{array}{l}\text { Zimmermann et al., } 2020 \\
\text { (40) J Craniomaxillofac } \\
\text { Surg }\end{array}$ & $\begin{array}{c}\text { Narrative Literature } \\
\text { Review }\end{array}$ & $\begin{array}{l}\text { The use of PPE should be selected adequately (depending on the planned procedure } \\
\text { and infection status) and used appropriately. There even might be the need for a } \\
\text { training of the staff concerning how to put on, remove, and dispose of the equip- } \\
\text { ment. For any type of surgery performed on patient FFP3 respirator/N99 respirator/ } \\
\text { equivalent, disposable sterile gown, sterile gloves, surgical hood cap and eye pro- } \\
\text { tection should be used. }\end{array}$ \\
\hline $\begin{array}{l}\text { Zhao et al., } 2020 \text { (41) } \\
\text { Br J Oral Maxillofac Surg }\end{array}$ & $\begin{array}{c}\text { Narrative Literature } \\
\text { Review }\end{array}$ & $\begin{array}{l}\text { First level protection: wearing work clothes, disposable work caps, disposable surgi- } \\
\text { cal masks, disposable isolation clothes and disposable latex gloves. Second level } \\
\text { protection: wearing disposable working cap, medical protective mask (N95), protec- } \\
\text { tive glasses, protective clothing or protective screen, disposable protective clothing } \\
\text { or disposable impermeable isolation clothing, disposable latex gloves, and dispos- } \\
\text { able shoe cover if necessary. Third level protection: on the basis of second level } \\
\text { protection using full face shield, full face respirator or positive pressure head cover. }\end{array}$ \\
\hline
\end{tabular}

PPE: personal protective equipment 
the operator involving a potential risk of transmission. Likewise, these microdroplets have the potential to float in the air for a considerable amount of time or the patient can cough or sneeze and leave the work environment contaminated (22). Furthermore, there could be secondary clinical contamination through a wound from the use of sharp or cutting instruments, and even from direct contact with the mucosa.

ACE2 has been shown to be the main host receptor for virus entry. ACE2 receptors are highly expressed in the lung, colon, and kidneys among other tissues. The expression of these receptors have also been verified in the oral mucosa, particularly in the epithelial cells of the tongue, in the buccal and gingival mucosa (24). Therefore, the oral cavity could be considered a source of infectious risk for COVID-19 and should be taken into account when establishing prevention strategies for the treatment of patients in the dental clinic.

The presence of the virus in saliva has been demonstrated, so it may have a fundamental role in the oral transmission of the virus $(25,26)$. It has been suggested that the SARS-CoV-2 can be observed in saliva by three different routes: first, the virus can get from the upper respiratory tract to the mouth. Secondly, through the crevicular fluid along with other elements from the serum. Finally, by infection of the salivary glands with direct release of the virus in the saliva through the drainage channels. In fact, salivary gland infection has been seen in animals (Macacus Rhesus) (11). Also, in experimental animal models, it has been seen specific SARS-CoV-2 A-Immunoglobulins secreted by saliva (27). It is even proposed that saliva can be a tool to detect the SARSCoV-2 (28).

Due to the special characteristics of the dental settings, strict protective measures during dental examination and treatment of the patients must be taken to be effective to prevent the spread of infection by this novel coronavirus. Therefore, certain modifications of standard precaution and infection control regimen targeted toward COVID-19 is essential during this outbreak.

-Dental patient evaluation

Previous phone screening

When a patient requests a visit, the possibility of infection should be identified through a basic telephone evaluation by asking about symptoms. It is necessary to identify the reason for the appointment. To clarify if it is a dental emergency, we will ask to the patient: Where exactly is the pain? When did it start, was it constant/ intermittent, gradual/ sudden? No patient should come without a previous screening by phone. Telephone questions should be able to identify a suspected case of $\mathrm{CO}$ VID-19. Patients should be asked for any COVID-19 symptoms and any recent contact with positive confirmed COVID-19 individuals, or whether the patient has passed the disease and how long he/she has been dis- charged. Moreover, we will ask if he/she has had fever, sore throat or cough in the last 2 weeks, as well as if he/she had diarrhoea or respiratory fatigue. It is important to know the type of occupation and if it is related to healthcare or socio-healthcare. After this screening, any suspected or confirmed COVID-19 patients' treatment should be postponed if possible for a few weeks unless it is a dental emergency $(29,30)$.

\section{-Clinical examination}

The patient must come alone to the appointment unless he/she is a minor, a disabled person or an elderly person. He/she must come to the appointment at the agreed time to avoid having more patients in the waiting room and he/she must come with the mask on. Upon arrival at the dental clinic, he/she should rub his/her hands with a hydroalcoholic solution and then wash his/her hands with soap and water for at least 40 seconds. Dental professionals should be familiar with how this novel virus is spread, how to identify patients with COVID-19 infection, and what extra-protective measures should be adopted during the practice, in order to prevent the transmission of COVID-19 (30). In addition, every visit should be used to implement preventive measures in maintaining proper oral health at home during the outbreak, especially in children (31). Before beginning the oral examination or dental treatment, the patient should perform a mouthwash with $1 \%$ hydrogen peroxide or $0.2 \%$ povidone for 1 minute $(12,32)$.

-Cross-infection control in Dental Clinic

Dental clinics stopped their activity except in the cases of dental emergencies in the various countries affected by the pandemic during the period of the outbreak to prevent the spread of the virus. However, after the pandemic outbreak, a restructuring will be necessary in the way of treating to patients with stricter preventive measures (32-42). -Cross-infection control according to risk areas

The different areas of the dental clinic must be considered for proper cleaning and disinfection taking into account the possible degree of exposure to the infection. There are areas of lower exposure (low risk) such as the reception or the waiting room where the accumulation of patients should be avoided by means of correctly arranged appointments. There are other areas of greater possibility of infectious exposure (high risk), such as the dental office, the operating room and the disinfection and sterilization room (32-41). Cleaning and disinfection of all clinic surfaces is necessary, including door handles, chairs and all types of surfaces in the clinical environment. Keyboards, screens, curing lamps, ultrasound equipment, and other technical equipment within the dental cabinet should be covered with plastic wrap. It is convenient to have all the necessary equipment prepared in the work area before starting the treatment to avoid opening drawers and wardrobes when the patient is in the cabinet. 
The cleaning and disinfection of the different surfaces will be carried out with a usual disinfectant for these areas (such us $70-75 \%$ ethanol solution) or with a $0.1 \%$ sodium hypochlorite solution, applying with sprays and a disposable cloth (35).

-Ventilation systems

Installation of enhanced air ventilation systems in dental cabinets can also help to facilitate the elimination of airborne pathogens and reduce the risk of infection (43). There are several methods to remove / filter contaminated air in treatment areas; one of the most commonly used devices is the high volume evacuator (HVE). It is the easiest way to remove dental aerosols as they are generated and could effectively reduce contamination caused by the operating site by $90 \%$. The HVE is a suction device that helps remove air at a rate of up to 2.83 $\mathrm{m}^{3}$ per minute (42).

-Prevention of aerosols spread during dental treatment If it is possible, the rubber dam should be placed because it prevents the formation of aerosols or splashes and a powerful aspiration must be placed (23). It is also convenient to use the high-speed handpiece with anti-retractive valves. A point where all current protocols coincide is the risk during dental treatment due to the formation of aerosols. These aerosols can be avoided with the use of a powerful surgical suction. In addition, studies have demonstrated that this backflow could occur during simultaneous use of other evacuation (high-volume) equipment Thus, the use of a single saliva ejector, preferably the high-volume evacuator is recommended $(23,42,43)$. Once the treatment is finished, the material should be left in a trough with disinfectant liquid to proceed to clean it later and once it has been thoroughly rinsed and dried, it is placed in the sealed sterilization bags following the usual procedure. The material is sterilized in the autoclave following the sterilization protocols for surgical instrument. The clinical waste generated by the treatment of patients will be considered as infectious medical waste and should go to double-layer yellow colour medical waste package bags with "gooseneck" ligation. The surface of the package bags should be marked and disposed according to the requirement for the management of infectious medical waste (21).

\section{Discussion}

It has been studied how the dentist is a health professional who presents a high risk of exposure to the COVID-19 (32-41). Regarding the personnel clinic, the first important measure to reduce the risk of cross infection is cleaning and disinfecting hands (32-41). Hand hygiene should be carried out before putting on gloves for the clinical examination of the patient or dental procedure and after finishing the treatment. Of course, at all times the dentist or assistant will avoid touching his/her mouth, nose or eyes. Personal protective equipment (PPE) must be used appropriately, such as a mask "Filtering Face Pieces class 2" (FFP2) or class 3 (FFP3), latex or vinyl long-sleeved gloves that are well suited, surgical cap, well-fitted protective glasses or goggles and face shield. All the clinic stuff should wear specific footwear with disposable wipes and a waterproof operating gown over the clinical uniform (32). All authors agree on the importance of the sequence of placement of PPE, affecting its effectiveness (32-41). The protocol for placing should be clear and all stuff must know it (32-41). PPE placement sequence: first put on shoe covers, then wash your hands for 40 seconds, then put on the waterproof gown, then the mask (FFP2 or FFP3) from behind, then the goggles, then the surgical cap, then the face shield and finally we will put on a pair of latex or vinyl long-sleeved gloves (32).

PPE removal sequence: just after the dental treatment, we will remove the face shield and then a pair of gloves to manipulate the patient's medical history, then we will remove the gown and the surgical cap, then we will clean the other gloves with hydroalcoholic disinfectant gel and we will remove the well-fitted protective glasses and the mask, and finally we will remove the other gloves and wash our hands.

To summarise, the results of the present review supports the high risk of COVID-19 cross infection among dentists and patients. Cross infection in the dental clinic involve a very important risk due to the return to dental settings after periods of social isolation of the population after the epidemic outbreak of SARS-CoV-2 (12). Therefore, we must take adequate and sufficient security measures to protect the patients and the dental clinic staff.

\section{References}

1. Meng L, Hua F, Bian Z. Coronavirus disease 2019 (COVID-19): Emerging and future challenges for dental and oral medicine. J Dent Res. 2020;99:481-7.

2. Mahase E. China coronavirus: WHO declares international emergency as death toll exceeds 200. BMJ. 2020;368:m408.

3. Zhou P, Yang XL, Wang XG, Hu B, Zhang L, Zhang W, et al. A pneumonia outbreak associated with a new coronavirus of probable bat origin. Nature. 2020;579:270-3.

4. Swerdlow D, Finelli L. Preparation for possible sustained transmission of 2019 novel coronavirus: Lessons from previous epidemics. JAMA. 2020;323:1129-30.

5. Pan X, Chen D, Xia Y, Wu X, Li T, Ou X, et al. Asymptomatic cases in a family cluster with SARS-CoV-2 infection. Lancet Infect Dis. 2020;20:410-1.

6. Kampf G, Todt D, Pfaender S, Steinmann E. Persistence of coronaviruses on inanimate surfaces and their inactivation with biocidal agents. J Hosp Infect. 2020;104:246-51.

7. Zhu H, Wang L, Fang C, Peng S, Zhang L, Chang G. Clinical analysis of 10 neonates born to mothers with 2019-nCoV pneumonia. Transl Pediatr. 2020;9:51-60.

8. He J, Tao H, Yan Y, Huang S, Xiao Y. Molecular mechanism of evolution and human infection with SARS-CoV-2. Viruses. 2020;12:428.

9. Hasan A, Paray BA, Hussain A, Qadir FA, Attar F, Aziz FM, et al. A review on the cleavage priming of the spike protein on coronavirus by angiotensin-converting enzyme-2 and furin. J Biomol Struct Dyn. 2020:1-9. 
10. Gheblawi M, Wang K, Viveiros A, Nguyen Q, Zhong JC, Turner AJ, et al. Angiotensin-Converting Enzyme 2: SARS-CoV-2 Receptor and Regulator of the Renin-Angiotensin System: Celebrating the 20th Anniversary of the Discovery of ACE2. Circ Res. 2020;126:1456-74. 11. Liu L, Wei Q, Alvarez X, Wang H, Du Y, Zhu H, et al. Epithelial cells lining salivary gland ducts are early target cells of severe acute respiratory syndrome coronavirus infection in the upper respiratory tracts of rhesus macaques. J Virol. 2011;85:4025-30.

12. Li ZY, Meng LY. Prevention and control of novel coronavirus infection in department of stomatology. Zhonghua Kou Qiang Yi Xue Za Zhi. 2020;55:217-22

13. Burhan E, Prasenohadi P, Rogayah R, Isbaniyah F, Reisa T, Dharmawan I. Clinical Progression of COVID-19 Patient with Extended Incubation Period, Delayed RT-PCR Time-to-positivity, and Potential Role of Chest CT-scan. Acta Med Indones. 2020;52:80-3.

14. Kokkinakis I, Selby K, Favrat B, Genton B, Cornuz J. Covid-19 diagnosis: clinical recommendations and performance of nasopharyngeal swab-PCR. Rev Med Suisse. 2020;16:699-701.

15. Ye X, Luo Y, Xia S, Sun Q, Ding J, Zhou Y, et al. Clinical efficacy of lopinavir/ritonavir in the treatment of Coronavirus disease 2019. Eur Rev Med Pharmacol Sci. 2020;24:3390-6.

16. Gautret P, Lagier JC, Parola P, Hoang VT, Meddeb L, Mailhe M, et al. Hydroxychloroquine and azithromycin as a treatment of $\mathrm{CO}$ VID-19: results of an open-label non-randomized clinical trial. Int J Antimicrob Agents. 2020;56:105949.

17. Fu B, Xu X, Wei H. Why tocilizumab could be an effective treatment for severe COVID-19? J Transl Med. 2020;18:164.

18. Hutton B, Catalá-López F, Moher D. The PRISMA statement extension for systematic reviews incorporating network meta-analysis: PRISMA-NMA. Med Clin (Barc). 2016;147:262-6.

19. Wang Y, Zhou CC, Shu R, Zou J. Oral health management of children during the epidemic period of coronavirus disease 2019. Sichuan Da Xue Xue Bao Yi Xue Ban. 2020;51:151-4.

20. Hua C, Liu Z, Wang Q, Yang Z, Xu Q, Zhang J. Strategy of dental clinics to cope with the epidemic period of infectious diseases based on the experience of corona virus disease outbreak. Hua Xi Kou Qiang Yi Xue Za Zhi. 2020;38:117-21.

21. Peng X, Xu X, Li Y, Cheng L, Zhou X, Ren B. Transmission routes of 2019-nCoV and controls in dental practice. Int J Oral Sci. 2020;12:9.

22. Ge ZY, Yang LM, Xia JJ, Fu XH, Zhang YZ. Possible aerosol transmission of COVID-19 and special precautions in dentistry. J Zhejiang Univ Sci B. 2020;21:361-8.

23. Barabari P, Moharamzadeh K. Novel Coronavirus (COVID-19) and Dentistry-A Comprehensive Review of Literature. Dent J (Basel). 2020; 8:E53.

24. Xu H, Zhong L, Deng J, Peng J, Dan H, Zeng X, et al. High expression of ACE2 receptor of 2019-nCoV on the epithelial cells of oral mucosa. Int J Oral Sci. 2020;12:8.

25. Khurshid Z, Asiri F, Al Wadaani H. Human saliva: Non-invasive fluid for detecting novel coronavirus (2019-nCoV). Int J Environ Res Public Health. 2020;17:2225.

26. Sabino-Silva R, Jardim ACG, Siqueira WL. Coronavirus COVID-19 impacts to dentistry and potential salivary diagnosis. Clin Oral Investig. 2020;24:1619-21.

27. Lu B, Huang Y, Huang L, Li B, Zheng Z, Chen Z, et al. Effect of mucosal and systemic immunization with virus-like particles of severe acute respiratory syndrome coronavirus in mice. Immunology. 2010;130:254-61.

28. Azzi L, Carcano G, Gianfagna F, Grossi P, Gasperina D, Geroni A, et al. Saliva is a reliable tool to detect SARS-CoV-2. J Infect.2020; 81:e45-50.

29. Alharbi A, Alharbi S, Alqaidi S. Guidelines for dental care provision during the COVID-19 pandemic. Saudi Dent J. 2020; 32:181-6.

30. Coulthard P. Dentistry and coronavirus (COVID-19)-moral decision-making. Br Dent J.2020; 228:503-5.

31. Yang Y, Soh HY, Cai ZG, Peng X, Zhang Y, Guo CB. Experience of Diagnosing and Managing Patients in Oral Maxillofacial Surgery during the Prevention and Control Period of the New Coronavirus
Pneumonia. Chin J Dent Res. 2020;23:57-62.

32. French Society of Stomatology, Maxillo-Facial Surgery and Oral Surgery (SFSCMFCO). Practitioners specialized in oral health and coronavirus disease 2019: Professional guidelines from the French society of stomatology, maxillofacial surgery and oral surgery, to form a common front against the infectious risk. J Stomatol Oral Maxillofac Surg. 2020;121:155-8.

33. Odeh N, Babkair H, Abu-Hammad S, Borzangy S, Abu-Hammad A, Abu-Hammad O. COVID-19: Present and Future Challenges for Dental Practice. Int J Environ Res Public Health. 2020;17:E3151.

34. Fiorillo L, Cervino G, Matarese M, D'Amico C, Surace G, Paduano V, et al. COVID-19 Surface Persistence: A Recent Data Summary and Its Importance for Medical and Dental Settings. Int J Environ Res Public Health. 2020;17: E3132.

35. Lo Giudice R. The Severe Acute Respiratory Syndrome Coronavirus-2 (SARS CoV-2) in Dentistry. Management of Biological Risk in Dental Practice. Int J Environ Res Public Health. 2020;17: E3067. 36. Mupparapu M. Editorial: Dental practitioners' role in the assessment and containment of coronavirus disease (COVID-19): Evolving recommendations from the Centers for Disease Control. Quintessence Int. 2020;51:349-50.

37. Ather A, Patel B, Ruparel N, Diogenes A, Hargreaves K. Coronavirus Disease 19 (COVID-19): Implications for Clinical Dental Care. J Endod. 2020;46:584-95.

38. Dave M, Seoudi N, Coulthard P. Urgent dental care for patients during the COVID-19 pandemic. Lancet. 2020;395:1257.

39. Spagnuolo G, De Vito D, Rengo S, Tatullo M. COVID-19 Outbreak: An Overview on Dentistry. Int J Environ Res Public Health. 2020;17:E2094.

40. Zimmermann M, Nkenke E. Approaches to the Management of Patients in Oral and Maxillofacial Surgery During COVID-19 Pandemic. J Craniomaxillofac Surg. 2020;48:521-6.

41. Zhao Z, Gao D. Precaution of 2019 Novel Coronavirus Infection in Department of Oral and Maxillofacial Surgery. Br J Oral Maxillofac Surg. 2020;58:250-3

42. Narayana TV, Mohanty L, Sreenath G, Vidhyadhari P. Role of preprocedural rinse and high volume evacuator in reducing bacterial contamination in bioaerosols. J Oral Maxillofac Pathol. 2016;20:59-65.

43. Villafruela JM, Olmedo I, Berlanga FA, Ruiz de Adana M. Assessment of displacement ventilation systems in airborne infection risk in hospital rooms. PLoS One. 2019;14:e211390.

\section{Authors' contributions}

Their individual contributions to the study was: Francisco Javier Silvestre: study design, data collection, analysis of the results, interpretation and drafting of the manuscript; Mayte Martinez-Herrera: study design and drafting of the manuscript and English translation; Cecilia Fabiana Márquez-Arrico: study design, analysis of the results, interpretation and drafting of the manuscript; Javier Silvestre Rangil: analysis of results, drafting on the manuscript and providing final approval of the version to publish.

\section{Source of funding}

CFMA is a recipient of a predoctoral fellowship from Ministry of Science, Innovation and Universities (FPU18/00854).

\section{Conflict of interest}

The authors declare no potential conflicts of interest with respect to the authorship and/or publication of this article. CFMA is a recipient of a predoctoral fellowship from Ministry of Science, Innovation and Universities (FPU18/00854). 